\title{
PENINGKATAN KEMAMPUAN GURU DALAM MEMANFAATKAN E-LEARNING MELALUI APLIKASI EDMODO
}

\author{
Yusri Wahyuni ${ }^{1}$, Riska Amelia ${ }^{2}$ Fauziah $^{3}$ \\ ${ }^{1,3}$ Pendidikan Matematika, ${ }^{2}$ Pendidikan Teknologi Ilmu Komputer, Fakultas Keguruan dan Ilmu Pendidikan \\ Universitas Bung Hatta \\ E-mail : yusri.wahyuni@bunghatta.ac.id
}

\begin{abstract}
Abstrak
Secara umum sekolah-sekolah SMP/MTs yang ada di Kecamatan Lengayang sudah tergolong sekolah dengan fasilitas yang baik. Hal ini terbukti dengan adanya jaringan wi-fi di sekolah yang dapat dimanfaatkan guru dan siswa. Namun hal ini tidak dimanfaatkan dengan baik oleh guru untuk menunjang kegiatan pembelajaran. Kurangnya kegiatan pelatihan yang diikuti oleh guru juga membuat kemampuan guru dalam membuat inovasi pembelajaran dengan pemanfaatan IT masih sangat kurang. Melihat kondisi tersebut, tim PKM beserta mitra berdiskusi untuk mencari solusi dari permasalahan prioritas yang ditemukan. Solusi yang ditawarkan adalah dengan memberikan pelatihan aplikasi edmodo kepada guru-guru matematika SMP/MTs se-kecamatan Lengayang Kabupaten Pesisir Selatan. Tujuan kegiatan ini adalah meningkatkan kemampuan guru dalam memanfaatkan e learning melalui aplikasi edmodo. Metode yang dilakukan dalam kegiatan ini adalah pendampingan. Untuk mengukur keberhasilan kegiatan pelatihan ini, dilakukan evaluasi dengan menggunakan instrument berupa angket. Berdasarkan hasil respon guru melalui pemberian angket setelah mengikuti kegiatan pelatihan ini, diperoleh bahwa 82,47\% peserta memiliki respon yang sangat baik pada kegiatan pelatihan yang dilakukan. Sehingga dapat disimpulkan bahwa peserta serius dan sangat antusias dalam mengikuti pelatihan, dan peserta juga merasakan bahwa pelatihan ini sangat bermanfaat untuk di aplikasikan dalam proses pembelajaran di kelas.
\end{abstract}

Kata Kunci: Pelatihan, e-learning, edmodo

\begin{abstract}
In general, SMP/MTs schools in Lengayang district are already classified as schools with good facilities. This proved to be a Wi-Fi network in schools that teachers and students can use. However, it is not well utilized by teachers to support learning activities. Lack of training activities followed by teachers also make the ability of teachers in making innovation learning with the utilization of information technology is still very lacking. Seeing the condition, the Community partnership Program team and Partners discuss to find a solution of the priority problem found. The solution offered is to provide Edmodo application training to JUNIOR/MTs mathematics teachers in Lengayang district South Coast District. The purpose of this activity is to improve the teacher's ability to utilize e learning through Edmodo applications. The method performed in this activity is mentoring. To measure the success of this training activity, evaluation by using instrument in a questionnaire. Based on the results of the teacher's response through a poll after following this training activity, it was obtained that $82.47 \%$ of participants had an excellent response to the training activities conducted. So it can be concluded that the participants are serious and very enthusiastic in the training, and participants also feel that the training is very useful to be applied in the learning process in the classroom.
\end{abstract}

Keywords: Training, e learning, Edmodo 


\section{PENDAHULUAN}

Perkembangan teknologi informasi dewasa ini sangat pesat sehingga mempengaruhi semua aspek kehidupan termasuk bidang pendidikan. Bidang pendidikan khususnya pelajaran matematika di tingkat sekolah dasar maupun menegah telah banyak berkembang media atau alat bantu yang dapat digunakan dalam mengajarkan konsep dasar matematika (Buntoro, Ariyadi, dan Astuti, 2018). Kegiatan pembelajaran yang masih bersifat konvensional akan berdampak pada kebosanan siswa dan pemahaman konsep yang sangat kurang. Pembelajaran akan lebih bermakna jika siswa terlibat langsung dalam proses pembelajaran, tidak hanya menerima apa yang disampaikan oleh guru (Wahyuni \& Alyusfitri, 2017).

Kurangnya pemanfaatan teknologi dalam pelaksanaan proses pembelajaran membuat guru kurang kreatif dalam merancang kegiatan pembelajaran. Hal ini berakibat pada rendahnya hasil belajar siswa.

Salah satu teknologi informasi yang popular digunakan sebagai model pembelajaran adalah e-learning. E-learning adalah pemanfaatan teknologi informasi dan komunikasi (TIK) untuk mentransformasikan proses pembelajaran antara pengajar dan peserta didik (Amelia \& Gufron, 2018).

Buntoro, Ariyadi, dan Astuti (2018) mengatakan E-learning sebagai media dalam proses pembelajaran diaplikasikan dengan teknologi internet yang mempunyai prinsip sederhana, personal, dan cepat. Untuk menambah daya tarik siswa, e-learning dapat dikembangkan dengan menerapkan teori games. Oleh karena itu, prinsip dan komunikasi pembelajaran perlu di desain layaknya pembelajaran konvensional. Terkait hal tersebut, pengembangan model e-learning yang tepat sesuai dengan kebutuhan sangat diperlukan ( Yazdi, 2012).

Menurut Somantri, Abidin, Wibiwo, dan Wiyono (2017) dengan dikembangkannya jaringan computer memungkinkan untuk dikembangkan dalam bentuk berbasis web, sehingga kemudian dikembangkan ke jaringan computer yang lebih luas yaitu internet. Penyajian e-learning berbasis web ini bisa menjadi lebih interaktif ( Yazdi, 2012 ; Arifin, 2009 ). Efendi, Lusiana, \& Muzawi (2019) mengatakan bahwa penggunaan internet maupun perangkat elektronik lain dalam pembelajaran e-learning memungkinkan pembelajaran bisa dilakukan dalam waktu yang sama atau berbeda.

Salah satu aplikasi e-learning yang dapat digunakan adalah Edmodo. Edmodo merupakan layanan berbasis internet yang disediakan sebagai sebuah jaringan belajar yang memungkinkan pengajar berbagi konten pembelajaran, memberikan kuis dan tugas, serta berkomunikasi dengan siswa, pengajar yang lain serta orang tua siswa (Hooland \& Muilenburg, 2011). Sukardi \& Hartanto (2018) mengatakan bahwa Edmodo merupakan salah satu media pembelajaran berbasis online yang dapat digunakan untuk mengontrol aktivitas siswa baik oleh guru maupun orangtua.

Berdasarkan pelatihan yang telah dilakukan oleh Awal, Wahyuni, dan Sari (2019) pada guru-guru SMP dan SMA Smart Indonesia Pekanbaru bahwa pelatihan aplikasi edmodo penting dilakukan karena hanya sebahagian kecil peserta yang pengetahui pengertian, kegunaan, maupun cara membuat akun Edmodo.

Secara umum sekolah-sekolah yang ada di Kecamatan Lengayang ini sudah tergolong sekolah dengan fasilitas yang baik. Hal ini terbukti dengan adanya jaringan wi-fi di sekolah yang dapat dimanfaatkan guru dan siswa. Namun hal ini tidak dimanfaatkan dengan baik oleh guru untuk menunjang kegiatan pembelajaran. Selama ini, SMP/MTs yang ada di Kecamatan Lengayang selalu berusaha untuk memaksimalkan waktu tatap muka dan bahkan penyampaian materi pelajaran dengan menambah jam belajar. Hal itu membuat siswa harus sekolah secara full day. Penyampaian materi di kelas selama ini berlangsung secara konvensional, sehingga menyebabkan siswa kurang bersemangat dan kurang termotivasi dalam pembelajaran. Kurangnya kegiatan pelatihan yang diikuti oleh guru juga membuat kemampuan guru dalam membuat inovasi pembelajaran dengan pemanfaatan IT masih sangat kurang.

Hasil wawancara dengan salah seorang Kepala Sekolah yang dilaksanakan pada bulan September 2018 diperoleh informasi bahwa frekuensi guru-guru khususnya guru mata pelajaran matematika yang ada di Kecamatan Lengayang dalam mengikuti pelatihan tingkat provinsi atau tingkat nasional masih sangat kecil. Oleh karena itu kemampuan guru matematika dalam membuat 
inovasi pembelajaran dengan menggunakan berbagai pendekatan dan memanfaatkan IT masih sangat rendah.

Memperhatikan kondisi sekolah SMP/MTs se-Kecamatan Lengayang yang kurang mendapatkan pelatihan khususnya guru matematika dalam membuat inovasi pembelajaran dengan menggunakan pendekatan pembelajaran yang memanfaatkan IT, maka beberapa Kepala Sekolah dari SMP/MTs se-Kecamatan Lengayang dan TIM PKM memandang perlu untuk melaksanakan kegiatan PKM ini. Kegiatan PKM ini dilaksanakan di MTsN Kayu Kalek, karena lokasinya yang mudah dijangkau oleh guru-guru matematika dari SMP/MTs yang ada di Kecamatan Lengayang.

\section{METODE}

Adapun tahapan prosedur tersebut antara lain:

a. Analisis situasi dan survey

Pada tahapan ini dilakukan survey dan wawancara langsung dengan mitra yang dituju yaitu SMP/MTs se-Kecamatan Lengayang Kabupaten Pesisir Selatan. Setelah itu dilakukan analisis terkait dengan situasi yang sedang berlangsung di tempat mitra. Pada tahapan analisis situasi ditemukan beberapa permasalahan yang dihadapi oleh mitra, salah satunya adalah kurang nya kemampuan guru memanfaatkan multi media yang sedang berkembang dalam proses pembelajaran.

b. Penentuan permasalahan prioritas

Berdasarkan kesepakatan antara tim PKM dan mitra ditentukanlah permasalahan prioritas yang harus segera dicarikan solusinya sehingga pada tahapan ini permasalahan utama sudah dapat ditentukan untuk diselesaikan. Permasalahan utama yang harus diselesaikan adalah kurangnya pemanfaatan multi media yang sedang berkembang dalam proses pembelajaran.

c. Solusi yang diusulkan

Tahapan ini adalah penentuan solusi oleh tim pelaksana PKM kepada mitra, sesuai dengan kesepakatan maka solusi yang diusulkan dijalankan sesuai dengan konsep dan metode yang telah ditentukan oleh tim pelaksana PKM dan disetujui oleh mitra. Tim PKM memberikan solusi berupa pelatihan kepada guru-guru dalam pemanfaatan e learning dengan menggunakan aplikasi edmodo.

d. Luaran

Pada solusi yang telah ditentukan, luaran yang diharapkan pada kegiatan PKM ini adalah guru matematika SMP/MTs se-Kecamatan Lengayang Kabupaten Pesisir Selatan memiliki kemampuan untuk memanfaatkan edmodo sebagai sumber belajar, dan juga dapat berkomunikasi dengan siswa, dengan orang tua siswa, dan juga dengan sesama guru.

e. Evaluasi dan pendampingan

Untuk mengukur sejauh mana tingkat keberhasilan dari kegiatan PKM yang telah dilaksanakan maka dilakukan evaluasi dan pendampingan. Tahapan ini dilakukan untuk men-sinkronkan antara tujuan dan harapan dari kegiatan PKM ini agar sesuai dengan luaran yang telah ditentukan. Evaluasi dilakukan dengan pemberian angket respon yang disebarkan kepada peserta pelatihan, setelah kegiatan dilaksanakan.

\section{HASIL DAN PEMBAHASAN}

Pelatihan dilakukan di KPN Lengayang pada hari selasa tanggal 9 April 2019. Dalam kegiatan ini, tim PKM berbagi tugas satu orang sebagai moderator dan dua orang sebagai narasumber. Kegiatan ini juga melibatkan tiga orang mahasiswa, yang bertugas memberikan pendampingan kepada guru-guru pada saat kegiatan berlangsung. 
Dalam melaksanakan pelatihan ini, peserta diberikan modul yang berisi petunjuk pengoperasian aplikasi edmodo. Pelatihan dimulai dengan meminta guru untuk membuka situs www.edmodo.com. Kegiatan pelatihan yang dilakukan adalah :

1) Membuat akun guru dan melengkapi profil

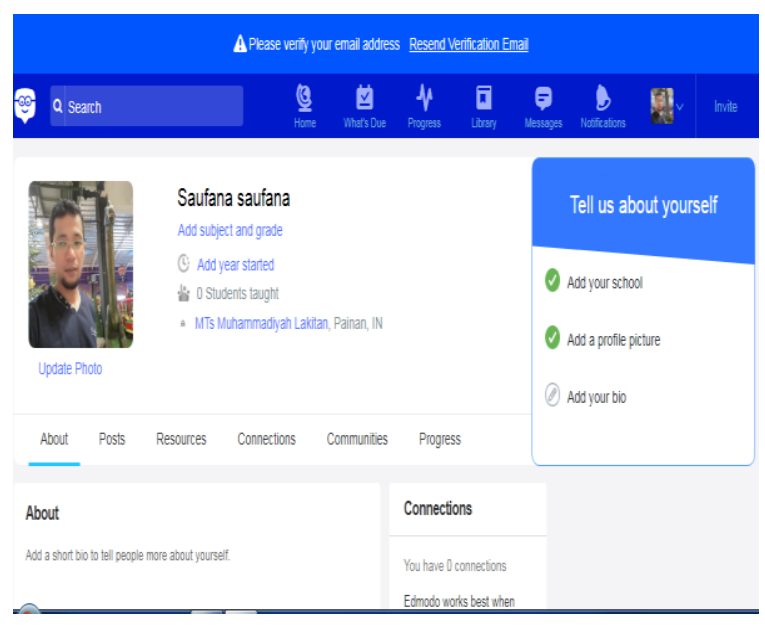

Gambar 1. Contoh Account salah satu peserta pelatihan dari MTs Muhammadiyah Lakitan, Painan

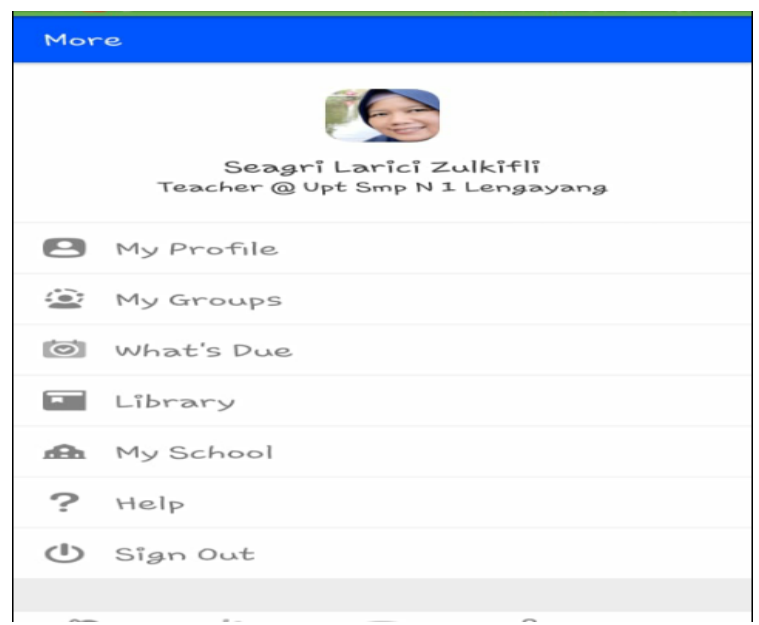

Gambar 2. Contoh Account salah satu peserta pelatihan dari SMPN 1 Lengayang, Painan

2) Membuat grup atau kelas virtual, dan bagaimana melihat kode akses kelas untuk siswa,

3) Cara memasukkan bahan ajar kedalam menu Library, membuat quiz, penggunaan fitur notes dan polling

4) Menjelaskan tentang menu gradebook (memberikan penilaian siswa). 
Pelaksanaan kegiatan PKM ini dibantu oleh mahasiswa yang berperan untuk melakukan pendampingan kepada peserta pelatihan.

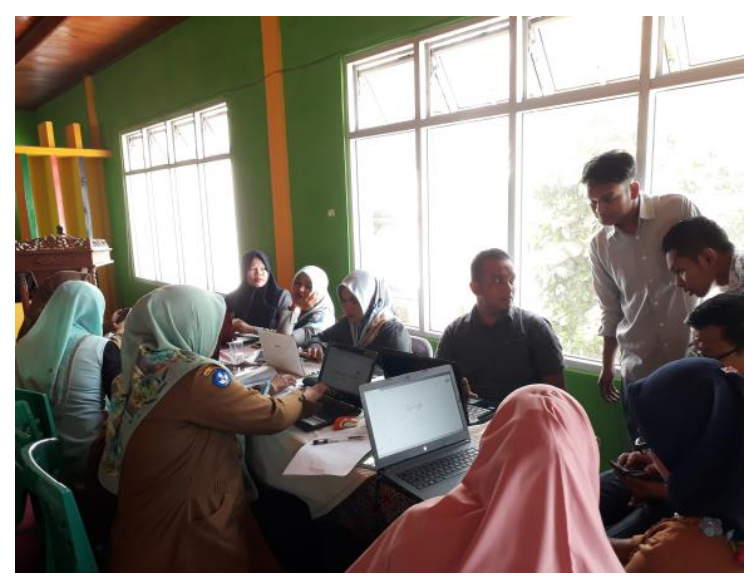

Gambar 3. Pendampingan oleh mahasiswa

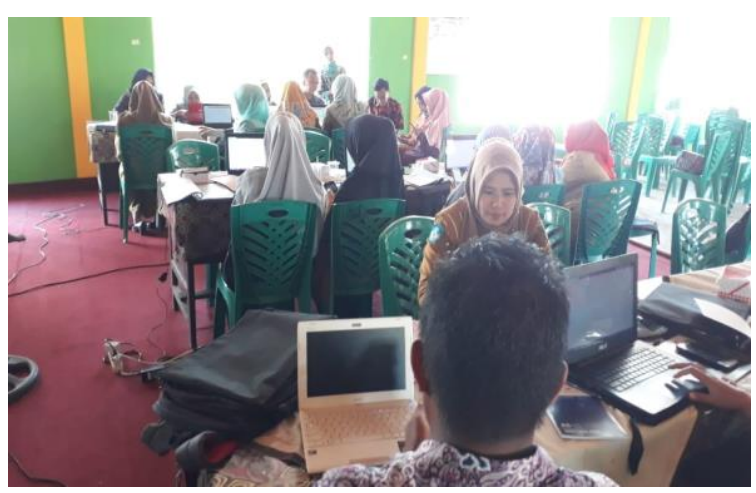

Gambar 4. Para peserta kegiatan pelatihan

Berdasarkan hasil angket dari respon peserta pelatihan yang terdiri dari 20 item pernyataan, dan diperoleh bahwa $82,47 \%$ peserta memiliki respon yang sangat baik pada kegiatan pelatihan yang dilakukan. Sehingga dapat disimpulkan bahwa peserta serius dan sangat antusias dalam mengikuti pelatihan, dan peserta juga merasakan bahwa pelatihan ini sangat bermanfaat untuk di aplikasikan dalam proses pembelajaran di kelas.

\section{SIMPULAN}

Pelatihan aplikasi edmodo yang telah dilaksanakan untuk guru-guru matematika tingkat SMP dan MTs se-kecamatan Lengayang telah berjalan sesuai jadwal yang telah disepakati bersama mitra. Berdasarkan tanggapan, respon, dan partisipasi dari para guru dapat disimpulkan bahwa guru merasa bahwa pelatihan ini sangat bermanfaat dan respon guru terhadap kegiatan pelatihan ini sangat baik yaitu sebesar $82,47 \%$. 
Guru mampu mengaplikasikan materi yang diperoleh dalam pelatihan sesuai dengan kebutuhannya. Guru juga sudah mampu berkomunikasi dengan guru lainnya dalam aplikasi, sehingga dengan aplikasi edmodo ini guru juga bisa saling berdiskusi dan berbagi materi pembelajaran.

\section{SARAN}

Dengan adanya pelatihan ini, diharapkan guru dapat membuat inovasi pembelajaran di kelas, dan guru juga mampu menyelesaikan kendala yang dihadapi dalam proses pembelajaran, lebih kreatif dan inovatif dalam melaksanakan pembelajaran di kelas. Dengan demikian, diharapkan untuk selanjutnya program pelatihan sejenis atau yang lainnya dapat dikembangkan demi terwujudnya pendidikan yang berkualitas, kreatif dan inovatif.

\section{UCAPAN TERIMA KASIH}

Penulis mengucapkan terima kasih yang sebesar-besarnya kepada kemenristek Dikti yang sudah memberikan bantuan dana melalui skim Program Kemitraan Masyarakat (PKM) tahun anggaran 2019 dan Lembaga Penelitian dan Pengabdian Masyarakat (LPPM) Universitas Bung Hatta Padang. Penulis juga mengucapkan terima kasih kepada mitra yang sudah sangat membantu pelaksanaan kegiatan pelatihan ini.

\section{DAFTAR PUSTAKA}

Amelia, Riska., \& Gufron. (2018). E-Learning Design Based On Learning Management System In Web Programming Course. International Journal Of Scientific \& Technology Research, 7(9) : 107-109.

Arifin, Z. (2009). Evaluasi Pembelajaran. Bandung : Remaja Rosdakarya.

Awal, Raudhah., Wahyuni, Sri., \& Sari, Marta. (2019). Pelatihan Menggunakan Aplikasi Edmodo Bagi Guru SMP dan SMA SMART Indonesia Pekanbaru. DINAMISIA-Jurnal Pengabdian Kepada Masyarakat, 3(1), 69-75.

Buntoro, Ghulam Asrofi., Ariyadi, Dwiyono., \& Astuti, Indah Puji. (2018). Pemanfaatan E-Learning Quipper School oleh Guru dan Siswa untuk Optimalisasi Pembelajaran di MAN 1 Ponorogo. Jurnal Pengabdian Kepada Msyarakat, 3(2) : 152-160.

Efendi, Yoyon., Lusiana., \& Muzawi, Rometdo. (2019). Workshop Mobile Learning Menuju Sekolah Berbasis Digital Pada SMK Negeri 1 Siak Kecil. DINAMISIA-Jurnal Pengabdian Kepada Masyarakat, 3(1) : 142-146.

Holland, C., \& Muilenburg, L. (2011). Supporting Student Collaboration : Edmodo in the classroom. In Society for Information Technology \& Teacher education International Conference (pp. 3232-3236). Association for the Advancement of Computing in Education $(A A C E)$.

Somantri, Oman., Abidin, Taufiq., Wibowo, Dega Surono., \& Wiyono, Slamet. (2017). Peningkatan Kemampuan Guru dalam Membuat E-Learning sebagai Media Pembelajaran Berbasis Teknologi Informasi di SMA Negeri 1 Subah. Jurnal Pengabdian kepada Masyarakat. 23(3): 332-337.

Sukardi \& Hartanto, Setyo. (2018). Pelatihan Pemanfaatan Media E-Learning Edmodo Di SMKN 2 Tulungagung. J-ABDIMAS (Jurnal Pengabdian kepada Masyarakat), 6(1) : 39-48.

Wahyuni, Yusri., \& Alyusfitri, Rieke. (2017). Analysis of Students' Mathematical Comprehension Ability Against Mathematics Teaching Materials with constructivism Through Mobile Learning System. IJRDO-Journal of Educational Research. 2(11) : 65-70.

Yazdi. (2012). E-Learning sebagai Media Pembelajaran Interaktif Berbasis Teknologi Informasi. Jurnal Ilmiah Foristek. 2(1) : 143-152. 